\title{
EL "VERDADERO ANTEMURAL DE LA NUEVA ESPAÑA" DOS PROPUESTAS PARA LA DEFENSA DE LAS CALIFORNIAS NOVOHISPANAS
}

\author{
THE “TRUE FORTRESS OF NEW SPAIN" \\ TWO PROPOSALS FOR THE MILITARY DEFENSE \\ OF THE NOVOHISPANIC CALIFORNIAS
}

\author{
Francisco Altable \\ Universidad Autónoma de Baja California Sur \\ Departamento de Humanidades \\ fiaf70@hotmail.com
}

\begin{abstract}
Resumen
La historia de las Californias novohispanas se inserta en el largo proceso de expansión colonialista de España. A lo largo de años y siglos, el interés por consolidar el dominio territorial de esa región estuvo marcado por los grandes mitos en torno de sus riquezas naturales, de su cercanía al fantástico estrecho de Anián y del comercio transpacífico con el Asia oriental. De ahí que la defensa militar de sus costas adquiriera una importancia capital con claras implicaciones geopolíticas, religiosas y económicas. El presente artículo aborda dos inéditas propuestas de carácter estratégico-militar, ambas con el objeto de asegurar la soberanía española en esa parte del mundo y sentar las bases de su poblamiento civil.
\end{abstract}

Palabras clave: Californias, navegación, defensa militar, poblamiento civil, soberanía territorial.

\begin{abstract}
The history of the Hispanic Californias is inserted in the long process of colonialist expansion of Spain. Over the years and centuries, the interest in consolidating its territorial domain was marked by the great myths surrounding its natural riches, its proximity to the fantastic Anian Strait and the trans-Pacific trade with East Asia. Hence, the military defense of its coasts acquired a capital importance with clear geopolitical, religious and economic implications. This article deals with two unknown strategic-military proposals, both in order to ensure Spanish sovereignty in that part of the world and the foundations of civil settlement.
\end{abstract}

Keywords: Californias, sailing, military defense, civil settlement, territorial sovereignty.

\section{Información del artículo}

Recibido: 16 de febrero de 2019.

Aceptado: 30 de julio de 2019.

DOI: 10.22201/iih.24486922e.2019.61.68519 
Algunos antecedentes sobre el asunto

En un informe de 1773, el renombrado José de Gálvez apuntó que la Antigua o Baja California era el "verdadero y único antemural" que tenía la Nueva España en el Mar del Sur. Esto, traducido en términos más actuales, significa que la península de California constituía la gran barrera natural que resguardaba el territorio novohispano. Cabe la precisión de que la protección del gigantesco escudo californiano sería parcial, pues el larguísimo litoral que corre entre Mazatlán y la desembocadura del río Suchiate (Chiapas) se abre de lleno a la inmensidad oceánica. Por consiguiente, lo dicho por el poderoso funcionario andaluz en realidad habría valido para las antiguas provincias de Culiacán, Sinaloa, Ostimuri, Sonora y la propia península de California en su ribera oriental. Diré de una vez que también le concedía al Pacífico californiano una ventaja tan grande como la de su índole defensiva, o quizás aún mayor: aseguraba que la ocupación de sus fondeaderos permitiría consolidar las relaciones comerciales entre China y las colonias americanas. ${ }^{1}$ Así, pues, Gálvez veía dos importantes conveniencias de carácter geoestratégico en la expansión de los intereses hispánicos en la región: una vinculada a las aspiraciones económicas y geopolíticas de la monarquía y otra ligada a la defensa militar de tales anhelos.

Gálvez estuvo de visita en la California meridional entre julio de 1768 y abril del año siguiente. Para entonces, el interés por esa aislada demarcación tenía una historia que se remontaba a las primeras décadas del siglo Xvi, cuando los hombres de Hernán Cortés - y Cortés mismo en 1535- exploraron el sur de una supuesta ínsula, a la que muy pronto se le atribuyó una vasta riqueza consistente en perlas y metales preciosos, se cree que, al menos en parte, por influencia de la literatura caballeresca de la época, de donde habría escapado el nombre que se le dio al nuevo descubrimiento: California, la fabulosa isla de las amazonas descrita en la novela de Garci Rodríguez de Montalvo. ${ }^{2}$

En el imaginario colectivo, California fue percibida como uno de los incontables cuerpos insulares que, con sus exuberantes mujeres y sus tesoros naturales, se sucedían en la inmensidad del mar como una sarta de paraísos terrenales. Se sabe, por ejemplo, que el conquistador de México organizó una expedición para explorar el litoral del Pacífico, porque allí,

${ }^{1}$ Informe al Consejo del ilustrísimo señor Gálvez, Madrid, 18 de diciembre de 1773, Archivo General de Indias (en adelante, AGI), Audiencia de Guadalajara, 418, exp. 274, ff. 543-582.

${ }^{2}$ Del Río (1985, pp. 19-27); Altable (2018, pp. 25-55). 
afirmaba, había muchas islas ricas en oro, perlas, gemas, condimentos “y muchos otros secretos y cosas admirables". ${ }^{3}$ De modo semejante, reyes, mercaderes y marineros vieron en California el comienzo de las Indias Orientales y su opulento comercio. Los ulteriores viajes que se efectuaron demostrarían que sólo había sido una ilusión: en California había perlas y, quizá, minerales de oro y plata, pero estaba lejísimos de los grandes mercados asiáticos; tampoco tenía el aspecto de un país frondoso y pletórico de sensuales nativas, ni se divisaban centros urbanos, actividad portuaria o embarcaciones mercantes. De hecho, a no pocos les pareció un lugar más bien seco, solitario y pobre: "Hay en la California - escribió el cronista Baltasar de Obregón por el año de 1584- altas sierras peladas; es isla espinosa, arcabucosa y poblada de caribes desnudos, gente la más rústica, deshonesta, sucia, vil y villana que se ha visto ni descubierto en las Indias". ${ }^{4}$

Para otros, no obstante, California siguió siendo una tierra de promisión: por largo tiempo perduró el interés por la pesca de perlas y la esperanza de que las montañas del interior ocultaran gruesos filones de metales preciosos, como los había en otras provincias del septentrión novohispano. Citaré dos entre muchos otros ejemplos: a principios del siglo XVII, el carmelita Antonio de la Ascensión, a cuyos escritos volveré más adelante, describió el paraje de San Lucas (Cabo San Lucas) en términos tan halagüeños como desmesurados. Subrayaba la conveniencia de poblar la tierra porque, en su opinión, podía llegar a ser la más importante del reino por las "varias y grandes riquezas" que encerraba en sus mares y montes, tantas, decía, que alcanzarían para pagar las cuantiosas deudas de la Corona. ${ }^{5}$ También por esa época, el empresario perlero Nicolás de Cardona se deshacía en temerarias conjeturas para convencer al rey sobre las bondades californianas:

[Por] lo que yo he visto, hallo que por sí es una de las tierras más ricas del mundo, porque en ella hay plata, oro, perlas, incienso, salinas [y] vasallos domésticos, que sólo falta hacer estimación de este reino y poblar alguna parte de él, la que más conveniente fuere para el servicio de su majestad y [así] aumentar sus rentas reales. ${ }^{6}$

Más tarde, a partir de 1565, dio comienzo el tránsito de galeones españoles a través del Pacífico septentrional, una vez que el conquistador Miguel

\footnotetext{
${ }^{3}$ Colección de documentos (1866, pp. 490-495); Ortuño Sánchez-Pedreño (2004, pp. 317-353).

${ }^{4}$ Del Río (1985, p. 36).

${ }^{5}$ Del Río (1985, p. 44).

${ }^{6}$ Colección de documentos (1866, p. 41).
} 
López de Legazpi pusiera las Filipinas bajo el dominio de la Corona española, y que el fraile Andrés de Urdaneta completara la ruta de regreso desde Cebú (y desde Manila seis años después) hasta la bahía de Acapulco. Este acontecimiento le concedió a California una importancia singular, toda vez que las naos procedentes del archipiélago asiático surgían frente a sus costas después de su larga navegación transpacífica; luego, los vientos y la corriente de California las empujaba hasta doblar el cabo de San Lucas y atacar el último tramo hasta echar anclas en el fondeadero acapulqueño. ${ }^{7}$ Por eso fue que se pensó en California como una posible escala para los barcos de la carrera filipina, en alguno de cuyos puertos podrían los tripulantes y pasajeros aprovisionarse de agua y alimentos, atender a los viajeros enfermos, hacer reparaciones a la nave o refugiarse en casos de inminente peligro, como un asalto de piratas o la embestida de una tempestad. ${ }^{8}$

El tercero de los incentivos que mantuvo vivo el interés por California fue el mito de un canal interoceánico que, según presunciones de los cosmógrafos, permitiría la navegación por el norte de América entre Europa y la China, lo que auguraba viajes más directos, seguros y gananciosos para el comercio de ultramar, en lugar de bajar hasta el estrecho de Magallanes, demasiado remoto y turbulento para los fines del mercado colonialista. ${ }^{9}$ Durante los siglos XVI y XVII, y aun a lo largo del XVIII, los españoles se empeñaron en descubrir el afamado y nunca visto brazo de mar. Había diversas hipótesis acerca de su localización geográfica, pero, partiendo desde el Pacífico novohispano, todas ellas conducían hacia California. Las hubo que lo situaron justo por encima de la gran "isla" californiana, como la del mencionado Nicolás de Cardona, que escribió lo siguiente: "Si estas noticias que me han dado [sobre el estrecho de Anián] son verdaderas, como yo creo [que] lo son, llegará a ser esto una de las cosas mayores del mundo, y por ninguna parte se podría llegar a reconocer y sujetarlo [mejor] que por la California, y descubrir la navegación que hay para España, que será viaje muy breve". ${ }^{10}$

Estas estimaciones se dieron algunos años después de que otro célebre navegante llevara a cabo dos expediciones a California enteramente financiadas con recursos del real erario. Me refiero a Sebastián Vizcaíno, hombre

${ }^{7}$ Carrera Stampa (1959, pp. 97-118); Portillo (1982); Fernández de Navarrete (1829); García-Abasolo González (2002, pp. 21-36); Landín Carrasco (1992, pp. 11-29).

${ }^{8}$ Yuste López (2007, pp. 21-44).

${ }^{9}$ Rodríguez (2015, pp. 133-144).

${ }^{10}$ Colección de documentos (1866, p. 41). 
muy experimentado en el pilotaje de las naos filipinas. El primer viaje se realizó en 1596 y tuvo como finalidad establecer, con nulos resultados, una colonia de españoles en la bahía de La Paz. El segundo viaje partió de Acapulco en 1602. En éste llevaba Vizcaíno la comisión de reconocer meticulosamente las costas californianas a fin de fijar con mayor precisión el lugar más conveniente para fundar la proyectada población de españoles. ${ }^{11}$ Los resultados fueron alentadores y de ahí surgieron dos propuestas generales: la del grupo de personas que respaldó el dictamen del comandante y la de fray Antonio de la Ascensión, que iba a bordo en calidad de misionero, capellán y cosmógrafo. Aquéllos aconsejaron la colonización del puerto de Monterrey, al sur de la bahía de San Francisco. El segundo recomendó el poblamiento de la bahía de San Bernabé (Cabo San Lucas), y lo hizo con declaraciones tal vez sobradas de honestidad, pero desproporcionadas en cuanto a la agradabilidad del clima y a la abundancia de recursos acuáticos y terrestres. A la postre, ninguno de estos veredictos se materializó en una expedición colonizadora, principalmente porque se interpuso un nuevo proyecto de descubrimiento y las Californias quedaron descartadas. ${ }^{12}$

Así que, por lo pronto, aquello que se pretendía erradicar siguió siendo un motivo de preocupación. Durante el siglo XVII y primeros años del XVIII, los ataques piráticos en el alto Pacífico novohispano se tradujeron en unos cuantos siniestros: la pérdida del galeón San Diego en 1610, del barco perlero perteneciente a los Cardona en 1615 y de la nao Nuestra Señora de la Encarnación en 1709. A pesar de esto, las pérdidas fueron comparativamente mucho menos numerosas que las habidas en el Atlántico hispanoamericano, aunque no por ello se quitó el dedo del renglón, menos aún, según parece, después de la incursión del corsario inglés George Anson entre 1742 y 1743, como nos lo hace ver Guadalupe Pinzón Ríos en uno de sus trabajos. ${ }^{13}$

Como bien se sabe, las mayores prioridades de defensa estaban en el golfo de México, en las Antillas y, con menor intensidad, en el Pacífico novohispano, centroamericano y peruano. Mientras tanto, las Californias permanecieron poco menos que despobladas e indefensas hasta las últimas décadas del siglo XVIII. A propósito de esto último, es preciso poner los ojos en la relación entre ausencia de poblaciones y desamparo militar, en el entendido de que, como dice Manuel Lucena, los atracadores del mar

\footnotetext{
${ }^{11}$ Altable (2003, pp. 52-58).

12 Altable (2018, pp. 55-107).

${ }^{13}$ Pinzón Ríos (2008, p. 84).
} 
preferían caer sobre los pueblos costaneros que andar a la caza de navíos mercantes en la inmensidad del océano, ${ }^{14}$ lo que podría asociarse con la ruta transpacífica de la nao filipina, que en muy contados casos fue objeto de atracos exitosos por parte de piratas y corsarios. ${ }^{15}$

Así y todo, la continuación del tráfico hispano-filipino, la incertidumbre circundante y la obstinación de encontrar el quimérico paso interoceánico impidieron el abandono definitivo de los planes de colonización y defensa militar para el litoral californiano. La última tentativa en este sentido fue la que protagonizó Isidro de Atondo y Antillón en 1683, tan fallida como las de sus predecesores y de cuyos esfuerzos apenas quedan vestigios de un inacabado fuerte militar en el paraje de San Bruno. Después, durante los setenta años de la administración jesuítica (1697-1768), lo más que llegó a consolidarse en materia de infraestructura castrense fue la pequeña fuerza compuesta de oficiales y soldados del llamado Presidio de Loreto, cuyo asiento principal estuvo en ese pueblo misional. Hasta ahí llegaron las cosas, a pesar de la notable expansión del sistema misional en dos terceras partes de la península y de las esporádicas disposiciones reales a fin de que los misioneros ignacianos y los sucesivos comandantes del presidio dieran pasos firmes hacia el establecimiento de pueblos civiles y fortificaciones militares en el Pacífico californiano. El de Felipe V quizá sea el más aludido de tales llamamientos, contenido en una cédula regia de $1744 .{ }^{16}$

Las circunstancias hasta aquí resumidas dieron paso a nuevas amenazas a todo lo largo del siglo XVIII, sobre todo por cuanto tiene que ver con la pretensión de frenar las hiperbolizadas incursiones de extranjeros a la caza de mamíferos marinos. Es en este contexto donde surge la vigorosa figura de José de Gálvez y su cauda de ordenanzas para las Californias, entre las cuales merecen justificada atención las destinadas a la defensa militar de los intereses regionales del régimen borbónico, que él, con amplísimas facultades, representaba en el virreinato. ${ }^{17}$ Desde su llegada a Veracruz en 1765 dio muestras claras de que la suya no sería una visita convencional. Ya instalado en la ciudad de México, comenzó a recibir una serie de informes acerca del estado que guardaban las provincias noroccidentales de Nueva España. De la revisión de tales documentos sacó en limpio ciertas conclusiones: que aquella región era extremadamente rica en perlas y mi-

\footnotetext{
${ }^{14}$ Lucena Salmoral (2005); Pinzón (2008, pp. 64-65).

${ }^{15}$ Pinzón (2008, pp. 74-76).

${ }^{16}$ Venegas (1943, pp. 316).

${ }_{17}$ Altable (2013, pp. 150-170).
} 
nerales preciosos, que estos bienes naturales estaban siendo mal aprovechados debido a la falta de colonos españoles, y que esa situación no variaba por la férrea oposición de los padres jesuitas y por los continuos ataques y pillajes que cometían las cuadrillas de indios rebeldes en Sonora. ${ }^{18}$ Asimismo discurrió que las condiciones de inseguridad podrían hacer que algún monarca extranjero planeara una invasión para adueñarse de tanta riqueza. Fue esto último lo que lo impulsó a declarar que California era el "verdadero antemural de la Nueva España”, la adarga que protegería los intereses del trono español contra las amenazas externas. Por eso, precisamente, hizo acto de presencia en aquella remota frontera.

¿Y quiénes eran esos que amenazaban la expansión del imperio en el noroeste novohispano? Eran varios, pero en concreto, por cuanto toca a la California septentrional, todo apuntaba al imperio ruso de Catalina la Grande. ${ }^{19}$ Lo más probable es que las intenciones de la emperatriz hayan sido sobredimensionadas en la corte madrileña, mayormente a raíz de los informes transmitidos por la diplomacia española desde San Petersburgo. ${ }^{20}$ Desmesuradas o no, el hecho es que los cazadores y comerciantes rusos fueron extendiendo sus actividades en el norte de las Californias al menos desde mediados del siglo XVIII, aunque no parece que se hayan establecido en colonias permanentes antes de los años ochenta. La falta de información precisa hizo que la imaginación y los temores fluyeran en Madrid y que tales aproximaciones fuesen percibidas como establecimientos fijos a manera de enclaves o puntas de lanza que apuntaban hacia un descenso ruso sobre el territorio californiano, o supuesto territorio californiano, ya que no existía ningún asentamiento español que diera sustento a dicho dominio territorial. ${ }^{21}$

${ }^{18}$ Informe al Consejo del ilustrísimo señor Gálvez, Madrid, 18 de diciembre de 1773, AGI, Audiencia de Guadalajara, 418, exp. 274, f. 543. Instrucción de Gálvez para el socorro de los indios de las misiones de la Antigua California, La Paz, 23 de noviembre de 1768, AGI, Audiencia de Guadalajara, 416, exp. 40, sin número de foja. Informe de Gálvez sobre el estado de las misiones del sur de la Antigua California, Real de Santa Ana, 8 de septiembre de 1768, AGI, Audiencia de Guadalajara, 416, exp. 40, f. 289. Del Río (1985, pp. 33-49, 57-58, 152-165); Altable (2013, pp. 33-47, 52-55).

${ }^{19} \mathrm{La}$ ausencia de otras naciones europeas en la explicación se debe a que los documentos consultados se centran en el caso ruso, lo cual, para otros estudios, desde luego no excluye las incursiones inglesas, francesas y holandesas en el Pacífico septentrional. Véase Pinzón (2011, pp. 99-135).

${ }^{20}$ Ruiz Rodríguez (2013, pp. 2-10).

${ }^{21}$ Bancroft (1886, vol. I, p. 113); Altable (2013, pp. 31-32, 414-467). 
Esta presunción se empató con una circunstancia inesperada: a mediados de 1767 se puso en ejecución el mandamiento real que obligaba a la Compañía de Jesús a abandonar todos los dominios españoles de manera prácticamente inmediata. En la península de California la orden se cumplió el 4 de febrero de $1768 .^{22}$

Estos dos asuntos - la presencia rusa y la expulsión de los ignacianostuvieron un efecto decisivo en los planes de Gálvez, pues pusieron en su agenda la necesidad de agregar la península de California al itinerario de viaje. ${ }^{23}$ En el puerto de San Blas, poco antes de embarcarse, convocó a varias personalidades civiles y militares con el fin de organizar una gran expedición conquistadora para fundar misiones y fortalezas en la Nueva California. ${ }^{24}$ También por esas fechas giró las instrucciones precisas para coordinar la salida de los jesuitas y su sustitución por frailes franciscanos. Ya establecido en el pueblo minero de Santa Ana (entre la bahía de La Paz y la misión de San José del Cabo), se propuso emplear parte de su tiempo en diseñar un plan de defensa para la región sureña en su conjunto.

\section{El informe de Miguel Costansó}

El documento predominante en este apartado fue suscrito en el mineral de Santa Ana a principios de septiembre de 1768. Ahí quedaron plasmadas las apreciaciones hechas por uno de los principales colaboradores de Gálvez, el subteniente de ingenieros Miguel Costansó, quien, aunque subordinado a la autoridad del influyente visitador, ya para ese entonces cultivaba un creciente prestigio profesional, en parte por las credenciales que le concedía el hecho de haber cursado estudios en la acreditada Academia de Matemáticas de Barcelona, y en parte por la importancia misma de sus trabajos en el campo de la ingeniería militar y de la demarcación geográfica, pues a este catalán se deben importantes planos y edificaciones, así como obras escritas de singular relevancia. ${ }^{25}$ Sin ninguna duda, su labor dio fundamento y viabilidad a varias de las instrucciones dictadas por el visitador general durante su estancia en el noroeste del virreinato; no obstante, el presente

${ }^{22}$ Del Río (2003, pp. 226-238).

${ }^{23}$ Altable (2013, pp. 58-73).

${ }^{24}$ Citado en Beebe y Senkewicz (2001, pp. 110-111).

${ }^{25}$ Véase Moncada Maya (1994); Capel (1994, pp. 11-21); Moncada Maya (2016); Costansó (1950). 
artículo ha de circunscribirse al informe que Costansó preparó sobre las condiciones que ofrecía el llamado paraje de San Lucas (Cabo San Lucas) para la defensa de los intereses españoles en el alto Pacífico novohispano. ${ }^{26}$

Como quedó dicho en el primer apartado, el afán de establecer un puesto militar en alguna parte de las Californias tenía una larga historia para el tiempo en que Gálvez llevó a cabo su visita. El paraje sanluqueño, en particular, había sido señalado en distintos momentos como un sitio apropiado para ese propósito. Es razonablemente probable que Gálvez y el ingeniero Costansó estuvieran al tanto de tales propuestas y llevaran consigo una idea preconcebida de lo que habría de hacerse en esa zona. De ser así, el viaje de reconocimiento que emprendieron ambos hacia San Lucas y los informes posteriores que prepararon habrían sido más una consecuencia lógica que un punto de partida.

A lo anterior apunta el hecho de que Gálvez, durante su estancia en el puerto nayarita de San Blas, previera la necesidad de reordenar las rutas hacia y desde las costas californianas a fin de reducir el número de naufragios y otros imprevistos mediante el aprovechamiento eficaz de las corrientes marinas y los vientos dominantes en la región. Decía el visitador que la experiencia generaba conocimiento acerca de los mares y sus litorales, lo que permitía una mejor definición de rumbos para las travesías de embarcaciones mercantes, exploratorias y militares, pero se lamentaba de que dicho beneficio no hubiera llegado todavía a las "peligrosas" aguas del Mar de Cortés, al que llamaban los marineros "golfo encantado", precisamente por la atribuida imprevisibilidad de los factores que podían conducir a un desastre o, al menos, a una "larga" y "penosa" singladura. "Puse especial cuidado - escribe el visitador-, desde que me embarqué en San Blas, en descubrir cuál sería el medio de hacer más breves los viajes de ida y vuelta desde dicho puerto a los de la costa de Sinaloa, Sonora y California”. ${ }^{27}$

No sé si es necesario aclarar que los ímpetus investigativos de Gálvez consistían en valerse del consejo profesional de sus asesores, en este caso, de Manuel Rivero Cordero, comandante naval de San Blas, y del piloto mayor Vicente Vila, a quien le confirió el altisonante título de "piloto en jefe de la Real Armada de España en la Mar del Sur”. Ese fue el venero de

${ }^{26}$ Relación del reconocimiento de la bahía de San Bernabé en el cabo de San Lucas, Real de Santa Ana, 1 de septiembre de 1768, AGI, Audiencia de Guadalajara, 416, exp. 40, ff. 283-286.

${ }^{27}$ Informe de Gálvez al marqués de Croix, virrey de Nueva España, Real de Santa Ana, 8 de septiembre de 1768, AGI, Audiencia de Guadalajara, 416, exp. 40, ff. 276-277. 
dónde sacó los argumentos para proponer reformas a las rutas marítimas de California. Para decirlo de una vez y sin alargarme demasiado, la propuesta del visitador fue que los barcos procedentes de la costa novohispana y destinados a la península de California navegaran mar adentro hasta dar con los vientos y corrientes que empujaban los grandes veleros hacia el cabo de San Lucas, para, desde ahí, internarse en el golfo de manera "fácil, cómoda y breve". En cambio, los buques que volvieran de la península a la Nueva España continental tendrían que costear las provincias de Sonora, Sinaloa y Nueva Galicia hasta fondear en su destino. ${ }^{28}$

Resulta pertinente traer a cuento este asunto porque la inteligencia práctica de los desplazamientos marítimos resultaba imprescindible desde el punto de vista de la geoestrategia militar. De poco serviría la construcción de baluartes sin un entendimiento claro de las condiciones oceánicas para la navegación hacia y desde los puestos de defensa. Por otra parte, el documento sugiere que el entorno del cabo sudcaliforniano, que Gálvez califica de "fértil" e "importante paraje", era concebido como punto neurálgico dentro de una concepción más amplia, que tenía como fin último la salvaguardia del noroeste novohispano, es decir, para hacer de la península californiana, como decía Gálvez, un antemural, que no sólo cumpliría con dicho fin, sino con el no menos importante de proteger, en estricto apego a los principios del mercantilismo, el tránsito de los cargueros españoles, grandes y pequeños, que surcaran el Pacífico septentrional. "Estoy firmemente persuadido - le comunicó al virrey - a que de esta manera queda facilitada la navegación del Golfo de California”. ${ }^{29}$

Gálvez y Costansó partieron hacia el sur de la península entre julio y agosto de $1768 .{ }^{30}$ La puntual descripción que hizo el subteniente de ingenieros de lo que ahí llama bahía de San Bernabé permite constatar que se trata de la actual bahía de Cabo San Lucas, cuyos médanos se extienden en dirección noreste-suroeste entre dos cabos, el de San Lucas en un extremo, con sus inconfundibles farallones en el remate de la tierra, y el de la Ballena, en la punta nororiental.

${ }^{28}$ Informe de Gálvez al marqués de Croix, virrey de Nueva España, Real de Santa Ana, 8 de septiembre de 1768, AgI, Audiencia de Guadalajara, 416, exp. 40, ff. 277-278.

${ }^{29}$ Informe de Gálvez al marqués de Croix, virrey de Nueva España, Real de Santa Ana, 8 de septiembre de 1768, AGI, Audiencia de Guadalajara, 416, exp. 40, f. 279.

${ }^{30}$ No tengo una fecha precisa para su salida del real minero de Santa Ana, pero si la de su retorno, que fue el 11 de agosto de 1768 . 
Al leer lo que expone Costansó en su informe, es inevitable la asociación con los antiguos Pareceres de fray Antonio de la Ascensión, el carmelita cosmógrafo que acompañó a Sebastián Vizcaíno durante la expedición de 1602. En ellos se detallan las grandes bondades que, a juicio del fraile, ofrecían los alrededores del cabo sanluqueño para la vida humana: una rada segura para los barcos, un clima benigno, agua potable, excelente pesca, abundante cacería y yacimientos de metales preciosos en la serranía del interior. ${ }^{31} \mathrm{El}$ propio Costansó da cuenta de aquel viaje de exploración en el siguiente pasaje: "A la misma bahía de San Bernabé aportó, dio fondo y refrescó su aguada el general Sebastián Vizcaíno con los navíos de su cargo, destinados al reconocimiento de la costa occidental desde el puerto de Acapulco [en] el año de 1602..."32

También él, al describir las inmediaciones de Cabo San Lucas, expuso las ventajas que ofrecía el lugar: la buena calidad de su "dulce, fresco y saludable" aguaje, la abundancia de alimentos marinos y su cómodo fondeadero, a cubierto de las tempestades veraniegas gracias a los cerros y peñones de la punta sudoccidental. Así que no parece demasiado aventurado decir que Gálvez y su colaborador conocían la opinión del carmelita descalzo, lo que da mayor peso a la hipótesis de que la elección de Cabo San Lucas fue anterior a la inspección in situ, efectuada por estos personajes, como digo, en agosto de 1768.

Tales atributos hacían de San Bernabé un surgidero "muy recomendable”, pues, según informes con que contaba Costansó, en ese sitio habían anclado varias embarcaciones en el pasado reciente sin que ninguna experimentara "la menor novedad", porque además, para mayor utilidad, allí no golpeaban las destructivas marejadas que de ordinario se presentaban en otras partes del Pacífico californiano, donde "la más ligera brisa” provocaba una mar de leva, esto es, aguas más o menos turbulentas y capaces de revolcar una lancha en proceso de aproximación a tierra, reduciéndola a un montón de astillas flotantes. El lugar no resultaba menos conveniente durante el otoño y el invierno. Decía el ingeniero que los nortes y noroestes no impedían el arribo de las naves y que cualquier escuadra de guerra podría atracar cómodamente, reabastecerse de agua, practicar las reparaciones precisas y emplearse en una "abundantísima" pesca. Por otra parte, la gruesa

${ }^{31}$ Altable (2018, pp. 72-83).

${ }^{32}$ Relación del reconocimiento de la bahía de San Bernabé en el cabo de San Lucas, Real de Santa Ana, 1 de septiembre de 1768, AGI, Audiencia de Guadalajara, 416, exp. 40, f. 283. 
arena del fondo mantendría las anclas "tenazmente agarradas" y el ahondamiento natural de la orilla permitiría fondear los barcos a corta distancia de la playa, como antes solían fondearse las naos de la China en busca de agua, comestibles, leña y alivio para los enfermos, y que ahora, por razones prácticas, lo hacían en la costa de San José del Cabo, un modesto pueblo de misión situado a unas cuantas leguas de San Lucas y administrado por un miembro de la orden franciscana a raíz del decreto de extrañamiento que cayó sobre la Compañía de Jesús en $1767 .{ }^{33}$

En suma, dejó asentado que San Bernabé constituiría un "excelente abrigo" para toda clase de embarcaciones durante la mayor parte del año y establecía con claridad la relación existente entre la información técnica de su estudio prospectivo y los categóricos fines a que respondía dicho análisis:

Por estas razones, y en virtud de órdenes positivas del rey, dadas en nombre de su majestad al virrey de la Nueva España, el excelentísimo señor marqués de Croix, se hace indispensable atender a la defensa y resguardo de este ventajoso sitio, porque en dichas órdenes encarga su majestad, muy expresamente, se ponga todo cuidado y vigilancia a la defensa de las costas de la California, y las que le son contiguas hacia el norte del continente de este vastísimo imperio, comunicando a su virrey individuales noticias acerca de las temerarias tentativas hechas últimamente por una nación poderosa, que, desde las más orientales regiones del Asia, ha pasado a registrar con fuerzas competentes las costas septentrionales de este mismo continente, ya sea con la mira de buscar el decantado paso de la Mar del Sur a la del Norte por la mar dicha del oeste, o con el fin de formar establecimientos sobre ellas, cosa que, verificándose, pudiera tener pésimas resultas y perjudicar notablemente los intereses de su corona. ${ }^{34}$

Varias cuestiones relevantes se desprenden de la cita textual: en primer lugar, se sugería que el proyectado bastión sudcaliforniano representaba la primera manifestación de un plan mayor para la defensa militar de las Californias - la del sur y la del norte-. Digo que tal era la sugerencia porque, como ya quedó declarado, para entonces Gálvez y sus colaboradores habían discutido y puesto en marcha las expediciones que habrían de culminar

${ }^{33}$ Relación del reconocimiento de la bahía de San Bernabé en el cabo de San Lucas, Real de Santa Ana, 1 de septiembre de 1768, AGI, Audiencia de Guadalajara, 416, exp. 40, f. 284.

${ }^{34}$ Relación del reconocimiento de la bahía de San Bernabé en el cabo de San Lucas, Real de Santa Ana, 1 de septiembre de 1768, AGI, Audiencia de Guadalajara, 416, exp. 40, f. 285. 
con la fortificación y ulterior colonización de la Alta California. Lo segundo es que la exploración del alto Pacífico americano seguía siendo un objetivo estratégico para los europeos en tanto no se descartara la existencia del fabuloso estrecho de Anián. Lo tercero es que las cosas se movían en tal sentido a causa de la incertidumbre, más o menos justificada, bien que siempre excesiva, sobre las aspiraciones y movimientos expansivos de la corona rusa. Por último, la advertencia de que, sin organización defensiva y con los súbditos de la emperatriz prácticamente encima, los intereses geopolíticos, religiosos y materiales de España estaban en inminente riesgo de malograrse en esa región del planeta.

Ahora bien, ni Gálvez ni Costansó planeaban la fortificación de Cabo San Lucas, es decir, la erección de una fortaleza o presidio militar como los existentes en otros dominios españoles - La Habana, Cartagena de Indias, Panamá, Veracruz, Callao, San Juan, Acapulco, entre otros-, sino en algo previsiblemente más eficaz y viable, dadas las precarias circunstancias demográficas y económicas de la provincia californiana. Lo que tenía que hacerse, dictaminó Costansó, era transportar hacia tierras sanluqueñas un número razonable de familias españolas y concederles, en posesión privada, parcelas cultivables, solares para la construcción de viviendas y dehesas para la cría de ganado mayor y menor. Una vez establecido el pueblo, los hombres aptos de la comunidad quedarían comprometidos en las actividades de defensa mediante la creación de una compañía de milicianos, en cuyo caso se obligaría el gobierno a proporcionar el armamento indispensable, los fueros militares y el nombramiento de un cabo como jefe de dicho cuerpo miliciano. Advierto de una vez que emplearé los términos "milicias" y "milicianos" cuando se haga alusión a las fuerzas de origen civil no asalariadas, adiestradas y capitaneadas por algún miembro del ejército profesional para la defensa circunstancial de un territorio.

Son interesantes los argumentos con que el ingeniero justificaba este modo de organizar la defensa regional. Sus conocimientos académicos le indicaban que una fuerza de doscientos milicianos bastaría y sería más útil que un pelotón de soldados "encerrados" entre los muros de una fortaleza militar, ya que, si el ataque enemigo lograba expugnar los muros, la derrota se traduciría en la pérdida absoluta de la península, a la cual no llegarían a tiempo los refuerzos desde el otro lado del golfo. Si, por lo contrario, los invasores acusaban debilidad, ¿para qué gastar en una costosa construcción los recursos que la economía californiana no producía ni la Corona tenía de sobra en su real erario? Bastaría con la población 
local, decía Costansó, porque esta era una gran conocedora del terreno y, por consiguiente, capaz de hacerle al invasor la vida imposible hasta someterlo, eliminarlo o forzar su fuga. ${ }^{35}$

Cabe anotar al margen una sencilla deducción que más abajo tendrá importancia al hablar de las instrucciones dictadas por Gálvez para el pretendido asentamiento de Cabo San Lucas: si Costansó estaba pensando en dos centenas de defensores, significa que la cantidad estimada de familias colonizadoras tendría que ser sensiblemente superior, considerando, como es lógico, la inclusión de cónyuges e hijos, y aun teniendo en cuenta que un determinado porcentaje de soldados lo compusieran hombres solteros. La cifra total podría suponer unos quinientos colonos, que no los tenía ninguno de los dos núcleos de población civil en la península; ni Loreto, la minúscula capital provincial; ni Santa Ana junto con los demás asentamientos mineros de la sierra sureña. ${ }^{36}$ Seguramente, sus cálculos se basaban en la ejecución del quimérico programa de inmigrantes que Gálvez había puesto en operación antes de cruzar el golfo, cuyos resultados fueron francamente desalentadores. ${ }^{37}$

La concurrencia de compañías de milicianos fueron un ejercicio parcial dentro del sistema de defensa novohispano. ${ }^{38}$ En lo relativo a la jurisdicción sureña de la Baja California, se formaron tres, todas de larga existencia: una bajo la jefatura del minero Antonio de Ocio, otra comandada por el capitán Bernardo Moreno y otra más a las órdenes del capitán Manuel García Morales, cada cual con alrededor de cuarenta milicianos, que quedaban de esta manera obligados a desempeñar funciones de carácter paramilitar, en la inteligencia de que ellos y sus proles se sostendrían con los productos de las tierras adjudicadas y la cría de animales domésticos. ${ }^{39}$ Los hombres así organizados quedaron al mando de suboficiales adscritos al presidio de Loreto, que, austero y lejano, constituía la única obra de fortificación militar a

${ }^{35}$ Relación del reconocimiento de la bahía de San Bernabé en el cabo de San Lucas, Real de Santa Ana, 1 de septiembre de 1768, AGI, Audiencia de Guadalajara, 416, exp. 40, f. 286. Informe de Gálvez sobre su viaje de inspección al cabo de San Lucas, Real de Santa Ana, 8 de septiembre de 1768, AGI, Audiencia de Guadalajara, 416, exp. 40, ff. 280-282.

${ }^{36}$ Trejo Barajas (1991, p. 34).

${ }^{37}$ Altable (2013, pp. 252-264, 284-318).

${ }^{38}$ Sobre las milicias es muy ilustrativo el trabajo de Pinzón (2011, pp. 185-209).

${ }^{39}$ Decreto de Gálvez, Loreto, 27 de abril de 1769, en Índice de los documentos que emitió el gobernador de la península de Californias para observancia de los puntos que en ellos prescribió el ilustrísimo señor visitador general don José de Gálvez, 5 de octubre de 1773, Archivo General de la Nación (en adelante, AGN), Provincias Internas, vol. 166, exp. 3, ff. $142-188$. 
todo lo largo de la península en tiempos de la visita de Gálvez. Más tarde se separó de Loreto una fuerza para la erección de un puesto defensivo cerca de la frontera entre la Antigua y la Nueva California, aunque sus instalaciones todavía fueron más rudimentarias que las de Loreto. ${ }^{40}$ Las fuentes indican que el primer comandante de los milicianos destinados a la defensa de San José del Cabo y Cabo San Lucas fue el capitán Manuel García Morales. ${ }^{41}$

No sólo inmigrantes, sino soldados retirados del servicio militar pudieron acceder a la posesión de predios rurales y “urbanos”. A quienes así lo pidieron, se les prorrogaron sus fueros militares y se les entregaron suertes de tierra, sitios de ganado y solares en el distrito minero de Santa Ana o en las tierras misionales de San José del Cabo y Santiago, todo ello a condición de que se integraran en alguna de las compañías milicianas en formación. La del capitán García Morales quedó formalmente subordinada a una partida de suboficiales y soldados del presidio loretano que Gálvez mandó destacar en las cercanías de San José del Cabo, y que fue, de cierto modo, una recomposición de la antigua Escuadra del Sur, creada tras el recio levantamiento indígena de 1734 y disuelta, según se cree, en el transcurso de los años cincuenta.

El 1 de noviembre de 1768 Gálvez firmó el documento por el cual dotaba a esa partida militar de una normatividad propia. Apenas dos suboficiales y ocho soldados la componían, todos sujetos a la autoridad superior del gobernador provincial, al capitán del distante presidio de Loreto $\mathrm{y}$ al teniente de gobernador que despachaba en el real de Santa Ana. El reglamento en cuestión dictaba que tres soldados, junto con sus familias, se trasladaran al paraje sanluqueño para encargarse de custodiar el lugar y dar aviso del paso o desembarco de extranjeros. Los vigías, apostados por turnos en "el más alto de los dos cerros cercanos a la punta del cabo", debían hacer ahumadas a los barcos españoles para que los pilotos supieran que había puerto seguro, más aún si se trataba del galeón de Manila. ${ }^{42}$

${ }^{40}$ Véase Altable (2013, pp. 76-93).

${ }^{41}$ Relación de la compañía miliciana capitaneada por Manuel García Morales, cabo de San Lucas, 13 de febrero de 1769, AGI, Audiencia de Guadalajara, 417, f. 98. Compañías de don Antonio de Ocio y don Bernardo Moreno, Santa Ana, 7 de noviembre de 1768, AGI, Audiencia de Guadalajara, 416, ff. 401-408. Extracto general que comprende las revistas ejecutadas a la compañía miliciana formada en la parte del sur desde el día 18 de octubre de 1799 , Loreto, 30 de febrero de 1800, y Ajuste de cuentas a la compañía miliciana establecida en la parte del sur de la península, México, 25 de febrero de 1801, AGN, Californias, vol. 6 bis, exp. 6, ff. 284-287.

${ }^{42}$ Reglamento para la escolta del Departamento del Sur de California, Santa Ana, 1 de noviembre de 1768, AGI, Audiencia de Guadalajara, 416, ff. 397-400. 
Así de empequeñecido quedó el ambicioso proyecto de Miguel Costansó para Cabo San Lucas, no sé si por la simple negativa del visitador o, lo más probable, por la impotencia que impuso la crónica escasez de recursos financieros, el evidente fracaso de la política inmigratoria del visitador y la adversa realidad peninsular, pues tampoco fue posible asentar familias de indios catecúmenos de San José del Cabo a orillas de la bahía de San Bernabé, como lo había decretado Gálvez. ${ }^{43}$ El capitán García Morales se vio impedido de cumplir con las ordenanzas de su jefe y así se lo comunicó al gobernador de la provincia en 1770 :

Se me hace preciso representar a vuestra superioridad el ningún efecto que estas [poblaciones de Cabo San Lucas] han tenido por haberme hallado imposibilitado de gente operaria para el trabajo y formación de ellas, pues, a más de la mortandad de naturales que hemos experimentado en esta península y sus misiones [...], también me han hecho falta ocho hombres que me estaban señalados por el ilustrísimo señor visitador general para este fin, pues habiendo empezado a trabajar con ellos en este real, en el tiempo de dos meses se me recogieron por el señor don Joaquín Velázquez [de León] para las minas de su cargo. ${ }^{44}$

Tendrían que pasar algunos años para que se concretara la vigilancia militar desde los cerros de Cabo San Lucas, pero el plan de Costansó para la formación de un pueblo de colonos milicianos simplemente se quedó en el camino.

\section{La propuesta de José María Beltrán}

Este oscuro personaje aparece aquí y allá en algunos textos, siempre de manera harto pasajera y en estricta relación con su carrera contable en la administración hacendística del virreinato novohispano, en concreto, de la Real Audiencia y Tribunal de Cuentas de la ciudad de México, institución

${ }^{43}$ Instrucción para el gobierno civil y económico de las misiones del sur de Californias, Real de Santa Ana, 1 de octubre de 1768, AGI, Audiencia de Guadalajara, 416, exp. 40, cláusulas 29 y 30. Informe de Gálvez, sin fecha, AGI, Audiencia de Guadalajara, 416, exp. 40, ff. 394-395.

${ }^{44}$ Manuel García Morales al gobernador Armona, Real de Santa Ana, 30 de junio de 1770, Universidad Autónoma de Baja California, Instituto de Investigaciones Históricas (en adelante, UABC-IIH), exp. 7.12, ff. 12-14, es copia de AGN, Californias, vol. 76, exp. 44. 
de la que llegó a ser contador mayor por decreto real de $1813 .{ }^{45}$ Sin embargo, su propuesta para colonizar y defender el litoral californiano, escrita, según parece, sobre su escritorio capitalino, viene a ser un buena muestra de cómo había perdido vigencia la vieja idea de que la mejor estrategia para salvaguardar las costas californianas era mantenerlas despobladas de españoles. En efecto, a principios del siglo Xviı, el virrey marqués de Montesclaros, por citar este entre otros ejemplos, había dicho que los enemigos de España procuraban los medios más accesibles para caer sobre los puertos de América occidental, pero la cosa se tornaba difícil porque ni daban con el ansiado paso interoceánico del norte, ni resultaba fácil rodear África para atravesar el océano Índico en ruta hacia el Pacífico, o entrar en esas aguas a través del estrecho magallánico. Entonces, se preguntaba, para qué levantar bastiones en una región donde rara vez surgían los barcos de las potencias rivales. En todo caso, lo más recomendable era la renuncia a establecer colonias españolas en esas costas, ya que establecerlas equivalía a abrir espacios para las actividades de saqueo e instalar una especie de trampolín para que los adversarios se lanzaran con más facilidad al ataque de los navíos filipinos. ${ }^{46}$ Sin embargo, los años transcurrieron y el Pacífico dejó de ser ese "lago español" que percibía el marqués. Los ingleses y los rusos acabaron convirtiéndose en una amenaza creciente, por no hablar de los holandeses y franceses, mientras aumentaba la necesidad de asegurar el territorio californiano que España llamaba suyo, pero que lo era solamente de manera nominal, salvo en el caso de la California jesuítica (aproximadamente entre los 23 y 30 grados de latitud norte). ${ }^{47}$

Mantener deshabitada la región pudo parecer conveniente para algunos en el pasado, pero en el siglo xviıI se llegó a la certeza de que ello deslegitimaba cualquier proclamación de pertenencia territorial y representaba una permanente invitación al desembarco de invasores ahora que los navíos extranjeros navegaban por el Pacífico en números crecientes y a sus anchas. Por esa razón cobró fuerza la idea de poblar por medio de colonos milicianos a fin de garantizar la expansión, la soberanía y la protección de

${ }^{45}$ Véanse Fuster Ruiz (1997, p. 546); Torales Pacheco (2001, p. 263); Zamora y Coronado (1840, t. 2, pp. 242-243); Sánchez Santiró (2017, p. 93), doi.org/10.1016/j. ehn.2017.05.002.

${ }^{46}$ Mathes (1965, vol. II, docs. 71 y 74).

${ }^{47}$ Son ampliamente conocidas las incursiones inglesas en el Pacífico y el intento de establecerse en la California continental al menos desde principios del siglo XVIII. Véase Pinzón (2011, pp. 110-111 y 130). 
las conquistas sin afrontar los tremendos gastos que implicaba la militarización mediante el emplazamiento de tropas y la construcción de recintos fortificados, entre otras pesadas obligaciones presupuestarias destinadas al sostenimiento de la institución castrense..$^{48}$ En esa modalidad ha de situarse el informe técnico de Miguel Costansó, pero conviene hacer la advertencia de que la propuesta del ingeniero catalán se regía por los dictados de una política pragmática que quedó lejos de ser la única en materia de defensa. La mejor prueba de esto es que la erección de fuertes y el envío de militares a la Nueva California tuvieron un marcado incremento como resultado de las expediciones organizadas por Gálvez entre 1768 y 1769, tras lo cual se fundaron cuatro importantes fortines en el curso de unos cuantos años: San Diego (1769), Monterrey (1770), San Francisco (1776) y Santa Bárbara (1782). ${ }^{49}$

Era obligación del comandante general de la Nueva California ordenar con oportunidad el despacho de correos y la preparación de las solicitudes de bastimentos. Al arribo de los barcos provenientes de San Blas y de las recuas que venían de la Antigua California, debía constatar que estuviesen listas las mulas de carga para la transportación de los mantenimientos destinados a los almacenes militares y a los pueblos de misión; estar al tanto del buen manejo de las cuentas e intereses provinciales de la Real Hacienda; proporcionar a los misioneros una escolta de guardia permanente y velar por la seguridad de los religiosos durante sus "entradas" apostólicas. ${ }^{50}$ En lo judicial, ordenaba la persecución y castigo de catecúmenos delincuentes o prófugos, lo mismo que de soldados amancebados con indias, entregados al juego de apuestas o señalados como culpables de cualquier comportamiento desordenado. ${ }^{51} \mathrm{Y}$ lo que más interesa aquí: tenía que procurar la formación de pueblos de españoles y organizar la vigilancia costera para tener bajo control las arribadas extranjeras e impedir el comercio ilícito y los asentamientos indeseados. Adviértase que el oficial en cuestión, además de las funciones inherentes a su condición de militar,

48 Véase Pinzón (2011, p. 85).

${ }^{49}$ Informe del gobernador Matías de Armona, Real de Santa Ana, 8 de agosto de 1770, UABC-IIH, exp. 7.15, ff. 1-5. Para todo lo relativo a la colonización de la California septentrional conviene tener a mano el texto de Ortega Soto (2001).

${ }^{50}$ Consulta de don Pedro Fages en que promueve varios puntos para el arreglo de los nuevos establecimientos que comanda, presidio de San Carlos de Monterrey, 2 de junio de 1773, AGN, Provincias Internas, vol. 211, exp. 17, ff. 337-340.

${ }^{51}$ Instrucciones de Pedro Fages al cabo de escolta de la misión de San Diego, sin fecha, AGN, Provincias Internas, vol. 211, exp. 17, ff. 341-344. 
en la práctica fungía como un agente activo en el proceso de implantación regional del colonialismo español y como el máximo defensor de los intereses españoles en la jurisdicción novocaliforniana.

No todas las aproximaciones extranjeras tuvieron un carácter bélico o pirático. Las hubo también con propósitos científicos (naturalismo, etnología, cartografía) o económicos (comercio, cacería de nutrias, ballenas, castores, lobos marinos, etcétera). Sin embargo, el temor de una arribada agresiva era constante y solía intensificarse durante las frecuentes guerras entre potencias europeas. De ahí que la Corona accediera con relativa facilidad a la hora de financiar expediciones exploratorias hacia el alto Pacífico norteamericano. ${ }^{52}$

Las amenazas de posibles recaladas extranjeras solían desembocar en apremiantes solicitudes de efectivos, armamento, obras de fortificación, barcos y demás. Estas solicitudes se atendían, aunque pocas veces con la rapidez y proporciones requeridas..$^{53}$ Los archivos resguardan una voluminosa cantidad de documentos relativos a las advertencias, que en este sentido hicieron militares y misioneros a lo largo del tiempo, sobre el mal estado de las instalaciones castrenses, el deterioro de uniformes, escopetas y espadas, la falta de buques cañoneros, la tardanza de los suministros, el desgaste físico de las bestias, el retraso de los salarios de la tropa, el riesgoso aislamiento de los establecimientos novocalifornianos y el corto

${ }^{52}$ Las más célebres exploraciones son la de Juan Pérez, que alcanzó en 1774 los $54^{\circ}$ de latitud norte y reconoció la isla de Nutka; la de Bruno de Heceta y Juan Francisco de la Bodega y Cuadra, quienes, en 1775, exploraron la llamada "Bahía de Bucareli"; la de Ignacio Arteaga y el mismo Bodega y Cuadra, que llegaron a los $59^{\circ}$ en 1779; la del italiano Alejandro Malaspina, entre 1789 y 1794; la que nuevamente dirigió Bodega y Cuadra hacia las bahías de Nutka en febrero de 1792. Véanse Expediente sobre la información obtenida de la expedición de descubrimiento de Ignacio Arteaga en 1779, AGN, Provincias Internas, vol. 73, exp. 10, ff. 415-418; Juan Francisco de la Bodega y Cuadra informa de sus operaciones en el puerto de Nutka, Monterrey, 24 de octubre de 1792, AGN, Historia, vol. 70, ff. 71-75. Bernabéu Albert (1992).

${ }^{53}$ Ignacio Arteaga al comandante de San Blas, San Blas, 4 de abril de 1781, AGN, Marina, vol. 49, exp. 15, f. 15. Copia de la instrucción que se le pasó al teniente de fragata don Juan Bautista Matute, San Blas, 24 de marzo de 1793, AGN, Historia, vol. 70, ff. 294-306. José Joaquín de Arrillaga al virrey, Loreto, 8 de marzo de 1802, AGN, Californias, vol. 22, exp. 7, ff. 8-9. Varios documentos relativos a la necesidad de reparar las fortificaciones y dotar de artillería a la Alta California, año de 1816, AGn, Provincias Internas, vol. 23, exp. 7, ff. 72-86. Pablo Vicente Solá al virrey, Monterrey, 21 de noviembre de 1816, AGN, Provincias Internas, vol. 23, exp. 10, ff. 98-100. Documentos relativos al aprovisionamiento de armas en los bajeles del rey que navegaban en el Pacífico californiano, año de 1776, AGn, Marina, vol. 37, exp. 6, ff. 254-265. 
número de soldados para resguardar un territorio con tanta población gentílica, tan extenso y tan "necesitado" de colonos españoles, todo lo cual, según informaban, era causa de frecuentes deserciones, actos de indisciplina e incompetencia en el ejercicio de las obligaciones marciales. ${ }^{54}$

Lo común era que los presidios y los miembros de las fuerzas armadas recibieran mayor atención en momentos de aparente peligro, digamos que ante los avisos de potenciales atracadas enemigas o por la sospecha de un levantamiento indígena. Podía ser que entonces la nómina y los abastecimientos se incrementaran, aunque nunca fue tanto que se llegara a hablar de plena satisfacción, pues siempre había prioridades más acuciantes adonde enviar el dinero y las armas, como el barril sin fondo de las guerras intereuropeas y la interminable lucha contra el corso y los contrabandistas en el mar Caribe. ${ }^{55}$ Pese a todo, las cuatro fortalezas erigidas, los pueblos civiles y la veintena de misiones franciscanas que se fundaron en la Nueva California constituyen el mejor testimonio de que la institución militar no fue inútil de cara a los intereses geopolíticos de la Corona borbónica.

${ }^{54}$ Neve a Bucareli, Monterrey, 26 de febrero de 1777, AGN, Provincias Internas, vol. 121, exp. 2, ff. 329-331, es copia en UABC-IIH, exp. 6.9, ff. 9-14. Estado que manifiesta la fuerza actual de las compañías presidiales de Californias, Arizpe, 9 de febrero de 1780, AgN, Provincias Internas, vol. 122, exp. 1, ff. 28-29. Estado en que se hallan las defensas de los presidios de San Francisco, Monterrey y San Diego, AGn, Provincias Internas, vol. 23, exp. 3, ff. 43-56. Expediente sobre la falta de caudales que había en San Blas para sus atenciones, Guadalajara, 23 de julio de 1816, AGn, Provincias Internas, vol. 218, exp. 3, ff. 107-110. Carta al virrey, México, 22 de septiembre de 1804, AGN, Californias, vol. 9, exp. 11, f. 436.

${ }^{55}$ El virrey da cuenta al ministro Julián de Arriaga del aumento concedido al Departamento de la Antigua California, México, 25 de febrero de 1776, AGI, Audiencia de Guadalajara, 515, doc. 37, ff. 608-611. Instrucciones de Bucareli a Neve, México, 25 de diciembre de 1776, AGN, Californias, vol. 13, exp. 7, ff. 264-278. El virrey a José de Gálvez sobre las providencias para auxiliar con hombres y ganados a los nuevos establecimientos de Californias, México, 27 de agosto de 1776, AGI, Audiencia de Guadalajara, 515, doc. 75, ff. 1123-1127. Lo mismo ocurriría en 1819, después de la toma de Monterrey, perpetrada por insurgentes bonaerenses en 1818. Véanse Informe sobre el estado de las Californias dado por el virrey conde del Venadito, año de 1819, AGI, Estado, 33, doc. 15 (1 bis); Refuerzo de tropa y artillería con que se ha dispuesto socorrer a los establecimientos de Californias para una oportuna defensa, 29 de julio de 1795, AGN, Correspondencia de Virreyes, vol. 181, ff. 195-196; Expediente sobre habilitación de dos fragatas del Departamento de San Blas para reconocer la costa y defender los puertos de la península de California, año de 1796, Agn, Marina, vol. 109, exp. 8, ff. 226-244; El gobernador de Californias dice haber recibido y circulado la real orden que trata sobre detener a los buques ingleses que arriben a los puertos de la península, Monterrey, 24 y 27 de marzo de 1797, AGn, Californias, vol. 74, exp. 43, ff. 129-132, es copia en UABC-IIH, exp. 6.38, ff. 1-7; Instancias instructivas para Jacinto Camaño, San Blas, 6 de marzo de 1797, AGN, Marina, vol. 109, exp. 8, ff. 258-259. 
Fue indesligable de este proceso el binomio soldado-colono, es decir, la idea de que los militares debían constituirse, a un mismo tiempo, en fuerza defensiva y en factores activos de la colonización civil. Lo hemos visto en los pretenciosos planes de Gálvez y Costansó para el paraje de San Lucas, y la California continental no representó una excepción en ese sentido. Muy pronto surgieron las voces que insistieron en la utilidad que devendría de la paciente evolución de los presidios hacia una condición civil. De hecho, desde los primeros tiempos se les dotó de una circunscripción de cuatro leguas a la redonda, de tal modo que hubiera el suficiente espacio para que, llegada la hora, se otorgaran a los soldados y a sus familias terrenos de uso privado y comunitario, destinados a las siembras, al ganado, a los pueblos y a los ayuntamientos. Si ya resultaba gravoso el presupuesto hacendístico en materia militar, por qué no procurar el ahorro y aprovechar la presencia de tropas con el doble objetivo de proteger, poblar y producir.

El catalán Pedro Fages, siendo comandante de la Nueva California (1770-1774), respondió a una consulta del virrey subrayando las ventajas de repartir tierras labrantías entre los soldados. Con base en ello, José Antonio de Areche, que por entonces se desempeñaba como fiscal asesor del despacho virreinal, estimó que las reparticiones debían hacerse alrededor de los fuertes militares, precisamente con la idea de combinar las tareas de defensa con la formación de asentamientos rurales y urbanos. ${ }^{56}$ Por su parte, el contador de armada Manuel Antonio de Soto firmó, a nombre del Real Tribunal de Cuentas de la ciudad de México, un extenso escrito donde quedaron listadas varias indicaciones relativas a la formación de pueblos, concesión de solares y parcelas, gobierno de misiones y construcción de fortalezas en las Californias. Muchas de ellas no fueron sino una reproducción de lo dicho y hecho por Gálvez y Costansó cinco años atrás, y pudiera decirse que ejemplificaban esa típica desconexión entre una racionalidad oficinesca y la distante realidad que dicha racionalidad pretendía transformar. En resumen, proponía el nombramiento de un "director de poblaciones", bajo el título oficial de "comandante director general de California", que estaría facultado para llevar a cabo proyectos de urbanización, planeación agrícola, erección de plazas, templos, edificios de gobierno, molinos y todo lo demás que condujera al "progreso" de la gobernación californiana.

${ }^{56}$ Fages a Bucareli, Monterrey, 2 de junio de 1773, AGN, Provincias Internas, vol. 211, exp. 16, ff. 334-336. 
Se oponía a los traslados de inmigrantes por considerarlos dispendiosos y respaldaba la propuesta de que se repartiera la tierra entre los soldados casados que servían en los fuertes militares, quienes acudirían a las armas en momentos de necesidad y el resto de su tiempo estarían al tanto de sus labores y ganados, que no era otra cosa que la vieja idea de organizar la defensa regional con base en la formación de fuerzas milicianas. ${ }^{57}$

Planteamientos como el anterior tuvieron escaso efecto en lo concerniente a la conducción de colonos. No obstante, los traslados, aunque pocos, se siguieron intentando, al menos hasta 1797 , año en que se fundó la fallida villa de Branciforte. Pero aún quienes simpatizaban con el establecimiento de fortalezas estaban convencidos de que sólo temporalmente sería aceptable el hecho de que los militares, por sí solos, o casi solos, sostuvieran la soberanía española en el Pacífico californiano. Se tenía claro que el verdadero fundamento regional de la monarquía sería, al fin de cuentas, la población civil y su cotidiano trajín en pos de la subsistencia.

Es así como llegamos a la propuesta del contador Beltrán, notablemente esclarecedora y redactada muchos años después de la visita de Gálvez y Costansó a la península californiana, remitida al virrey de Nueva España en respuesta a un informe del gobernador provincial, informe que tenía por objeto, entre otros, gestionar mayores recursos para los cuatro presidios de la Alta California. ${ }^{58}$ El contenido del documento en cuestión bien podría relacionarse con los manuscritos de conspicuos impulsores del reformismo borbónico en el norte de Nueva España, personajes como el marqués de Altamira, el visitador José Rafael Rodríguez Gallardo y el propio José de Gálvez, quienes, valiéndose de las ideas ilustradas en boga, cuestionaban la suficiencia de los bastiones para los fines de la defensa territorial. ${ }^{59}$

José María Beltrán parte de la más elemental lógica aritmética en el intento de demostrar la insensatez implícita en la pretensión de defender las Californias con la flaca asistencia de fuerzas acuarteladas. El litoral altacaliforniano, decía, rondaba los 720 kilómetros y a su defensa confluían 305 soldados y 100 milicianos, lo que daba para situar a poco menos de dos defensores por kilómetro. Pero si se apostara un individuo por cada metro

${ }^{57}$ Informe del contador Manuel Antonio de Soto, México, 12 de julio de 1774, UABC-IIH, exp. 8.7, ff. 4-48, es copia del expediente en AGN, Provincias Internas, vol. 211, exp. 3, sin número de fojas.

58 Informe de José María Beltrán, México, 21 de abril de 1800, AGn, Californias, vol. 9 , exp. 11, ff. 492-505.

${ }^{59}$ Osante (2012, pp. 119-164); Covarrubias (2005, pp. 278-296); Altable (2015, pp. 30-52). 
lineal, cavilaba, quedarían 719 kilómetros sin protección, esto es, alrededor del 99.96\% de la orilla marítima; “yo quisiera preguntar —añadía-cuál es el número fijo para que la costa quede protegida, pues no se sabe que haya en el mundo ejército tan numeroso, ni soberano que pueda soportar [los costos]" de semejante guarnición.

Me hago cargo de que Beltrán manejaba con exageración y efectismo las cifras. ¿̇A qué gobernante le vendría la imposible ocurrencia de emplazar un soldado en cada metro de una línea costera? No obstante, el artificio argumentativo le sirvió para entrar en una ruta discursiva que no carecía de buen juicio, cuanto más que estaba en consonancia con una vieja fórmula, la misma que enfatizaron, treinta años antes, José de Gálvez, Miguel Costansó y tantos otros: la potencia defensiva de las fortificaciones californianas y los recursos hacendísticos para acrecentarla siempre serían insuficientes, de modo que se imponía la necesidad de una intensa colonización civil. Beltrán afirmaba que "de la soledad nacía el riesgo y de la compañía la seguridad, y que debía tenerse por menos expuesto al país que estuviese más poblado". En otras palabras, existía una dependencia virtuosa entre defensa, población y soberanía.

También alegaba que la cantidad de pobladores crecía "en razón directa de la subsistencia, facilidad y comodidad de la vida", y que tales condiciones se hacían presentes con el fomento a la agricultura, lo que parece una afirmación cercana a los principios esenciales de la escuela fisiocrática. Cualesquiera que hayan sido sus fundamentos ideológicos, el hecho es que le parecía impostergable la conversión de los pueblos misionales y civiles de la Alta California en establecimientos proveedores de excedentes agrícolas y ganaderos para otras provincias novohispanas, pues pensaba que de esa manera cabría la esperanza de lograr un campo próspero, una población prolífica y una defensa robusta. A su parecer, estos eran los principales factores de la consolidación territorial, que se hacía por demás inaplazable ante la atrevida penetración marítima, ya no sólo de los rusos y británicos para ese entonces, sino de los estadounidenses. Explicaba que estos últimos, en opinión de algunos escritores de habla inglesa y francesa, ya se iban constituyendo en una "cada vez más formidable" potencia, y tendían a convertirse en los "rivales domésticos de las Américas".

En vista de todo ello, advertía sobre la falsa ilusión de un gasto militar tan ineficaz como excesivo. En cambio, se decía amigo de mantener, a un mismo tiempo, una mínima organización militar y los "indispensables" programas de inmigrantes, que únicamente precisaban de financiación en 
el comienzo y no tardaban mucho en arrojar buenos resultados en lo concerniente a la procreación familiar, la comercialización de productos y los ingresos fiscales.

Mientras que el gobernador de las Californias pedía que se incrementara el número de efectivos, el contador Beltrán, en cerrada oposición, recurría a su propia síntesis histórica sobre la organización militar, a concepciones económicas de elevada autoridad y a razones de carácter financiero. Sin afán de aburrir al lector, incluyo la siguiente cita por extenso porque, además de poseer un espíritu ilustrativo difícil de mejorar, resulta una interesante lección de geopolítica:

Si el sistema seguido por más de dos siglos y medio no acredita prosperidad; si los establecimientos extranjeros adelantaron y cada día hacen progresos llevando la regla inversa; si las Californias, cuya primera consignación fue de trece mil pesos [y ahora] ya pasa de cien mil, ¿̇no será debido mudar de método, imitar a los que consiguieron los fines de los establecimientos e impedir nuevos gravámenes a la Real Hacienda [...], seguir y observar las sabias disposiciones de las leyes, que no encargan para las colonias tropas armadas, sino brazos asidos de la esteba y del arado? Un millón de pesos cuestan las tropas presidiales de las Provincias Internas, y si este gasto anual se hubiese aplicado desde sus principios a formar poblaciones [en] la Sonora, no estaría cerrada la comunicación que tiene el río Colorado con la Alta California, y ésta proveería por el mismo camino a toda la Nueva España de sus preciosos frutos. [...] La historia que cita [el gobernador Diego de Borica] acerca de los establecimientos ultramarinos de las naciones europeas en el Asia prueba contra su intención, porque allí se registran, con harto dolor, los ningunos progresos de las islas Filipinas y los crecidos adelantamientos de las [colonias] inglesas, francesas y holandesas [...]. El señor gobernador no tiene obligación de saber que los situados de las islas de Barlovento y Sotavento no bajan cada año de cinco millones de pesos fuertes, que causan graves aflicciones al gobierno y hacen la más considerable falta para infinitas atenciones de la Corona [...]. El ministro [secretario de Indias] va huyendo de que las Californias se acostumbren al situado y de que los cien mil pesos presentes pasen a ser un millón. Cuando el país, por su esterilidad y situación fronteriza, no da esperanzas de agricultura, artes y comercio, será bien que se conserve a fuerza de guarniciones militares, pero un territorio como el [de] California, cuyo retrato es el mismo que dibuja el autor de las riquezas de Inglaterra, [es decir], una provincia que brinda con sus riquezas naturales y ofrece campo para otro imperio mayor que el mexicano, exige, en la constitución actual de los negocios públicos, que se cultive, fomente y pueble más por medios políticos que militares. Los ingleses y franceses, según [Bernardo] Ward, en los principios siguieron en sus colonias el sistema de los españoles y, 
después de un siglo, lo variaron, dando la última mano a esta grande obra la Junta de Comercio y Plantaciones, con tan feliz progreso, que las colonias francesas consumen dieciséis millones y las inglesas consumen cinco y rinden quince y medio, pagando los isleños los sueldos de sus gobernadores y costeando en gran parte el gasto de policía y defensa. ${ }^{60}$

Así, pues, me quedo con la idea de que la construcción de murallas defensivas en el alto Pacífico novohispano significaba para Beltrán dar continuidad a un sistema de defensa y poblamiento caro y obsoleto, habida cuenta de otras prácticas que, a su juicio, habían demostrado su efectividad en las colonias británicas y francesas, más aún porque las propias leyes españolas favorecían el método de colonias agrícolas y compañías comerciales para la colonización de nuevos territorios. El contador capitalino pensaba que, a la ineficacia de los recintos fortificados como instrumentos de poblamiento, se añadía el problema de la mala distribución de los recursos hacendísticos, los cuales, en lugar de dar apoyo a la producción económica de las localidades, terminaban disolviéndose en los "improductivos" desembolsos que hacía el real erario en concepto de situados, es decir, en los suministros que se embarcaban regularmente hacia los presidios californianos como remuneración por los servicios del personal militar. Si, en cambio, se hubiese invertido el dinero público en el traslado de colonos y en sus labores productivas, la cuenca del río Colorado, aseguraba, no estaría deshabitada de españoles, ni sería intransitable como lo era hasta entonces, ni serviría de obstáculo para que la Alta California contribuyera con su prosperidad a la protección de la ruta entre las Filipinas y Nueva España, como había soñado el navegante Sebastián Vizcaíno dos siglos atrás.

\section{Reflexión final}

De cierta manera, en los dos casos abordados asistimos a una suerte de revisión histórica en torno de las fallas y virtudes del sistema de presidios, entendido como mecanismo institucional para la defensa y expansión de los intereses españoles en aguas del Pacífico californiano. A la vez, estamos ante un discurso ennoblecedor de los programas de colonización

${ }^{60}$ Informe de José María Beltrán, México, 21 de abril de 1800, AGN, Californias, vol. 9, exp. 11, ff. 501-503. 
civil, concebidos a modo de rutas fiables hacia la dominación del litoral californiano, menos como un fin en sí mismo y más como medio para asir ciertos objetos importantísimos: el cercamiento de la riqueza metalífera del septentrión novohispano, la apropiación del elusivo canal interoceánico del norte, la hegemonía comercial en las relaciones hispano-asiáticas, la seguridad transoceánica de las naos manileñas, la expulsión del comercio extranjero y, a su hora, el aprovechamiento de las bondades naturales de la propia región californiana, las conocidas (pieles finas, perlas, sal, plata y productos de ballena) y también las desconocidas.

Subrayé antes la notable cercanía de las dos propuestas aquí examinadas con el espíritu reformista de la época, tan cercano al de los ministros e intelectuales de la corte madrileña durante la segunda mitad del Siglo de las Luces, por ejemplo, respecto de la variación del sistema de defensa mediante la incorporación de paisanos organizados en milicias, proposición que, por lo demás, ya se practicaba en el virreinato en medio de grandes limitaciones. ${ }^{61}$ Como dije párrafos arriba, en el departamento sureño de la Baja California se mantuvieron tres compañías milicianas, pero no podría establecer una relación positiva entre su existencia y los tímidos avances económicos y demográficos de la población sureña en los años postreros del periodo colonial.

La crítica de José María Beltrán en realidad no constituye más que un reflejo de lo que decían Gálvez y Costansó tres décadas atrás. En algún momento, el ingeniero barcelonés igualmente recomendó la traslación de familias colonizadoras como la medida más indicada para poblar y fomentar el comercio y la producción de las Californias. ${ }^{62}$ No obstante esta coincidencia, en el imaginativo relato de Beltrán el incremento de fuerzas militares sólo podía justificarse como una solución de inicio, hasta que los programas migratorios y la producción privada surtieran, poco a poco, el efecto deseado.

Entonces, tenemos enfrente dos posiciones sólo en apariencia incompatibles: una que patrocinaba la combinación de instrumentos estratégicos y otra que veía en la creación de plazas fortificadas un tragadero de recursos fiscales a mediano plazo. En la marcha de las circunstancias, las cosas no fueron tan contradictorias como parecían serlo en la argumentación del contador Beltrán: la ruda sequedad de la Baja California hizo del presidio

${ }^{61}$ Pinzón (2011, p. 198).

${ }^{62}$ Ortega (2001, p. 139). 
loretano, y de sus extensiones en el sur y en el norte de la península, una institución, si no magnífica, sí al menos capaz de contribuir a una pausada pero efectiva colonización civil, como quedó demostrado durante el largo proceso, inaugurado por Gálvez en 1768, de repartición de terrenos cultivables, sitios de ganado y solares urbanos, muchos de los cuales fueron otorgados a soldados y oficiales de dicha guarnición, quienes, por esa vía, se convirtieron en los primeros rancheros de la región. ${ }^{63}$ Por el contrario, la Alta California contaba con agua y tierras feraces. Al paso de algunos decenios sus ranchos agrícolas y ganaderos rebasaron la producción bajacaliforniana y, a resultas de ello, la provincia también superó a su homónima del sur en los índices de población. Al menos en teoría, la California del norte se prestaba de mejor manera a la inmigración masiva de colonos. No ocurrió tanto, pero el caso fue que, al lado de las escasas familias de inmigrantes y de la incorporación de indios gentiles a la sociedad española, también calaron hondo las raíces militares en el proceso de expansión civil durante la última parte del régimen colonial. ${ }^{64}$

En los hechos, la Corona estuvo dispuesta a impulsar ambos métodos, y es fácil comprender por qué era deseable ahorrar en gastos, mas no recomendable suprimir las fortalezas californianas ni el ejercicio profesional de la defensa armada. Por otro lado, era imprescindible, pero también complicado y lento, el proceso de poblar la tierra con familias colonizadoras a objeto de consolidar la soberanía española en la región. Lo conveniente, en todo caso, era que lo uno complementara a lo otro, pues así, como en su momento dijo el visitador Gálvez, resultaba más fácil levantar en las Californias el "verdadero antemural de la Nueva España".

\section{BibLIOGRAFÍA}

Altable, F. (2018). Las traviesas ninfas del dios Oceanus. Mito, fascinación e interés durante la exploración del Pacífico californiano. En F. Altable (coord.), Mar del Sur. Entre el mito y la realidad, siglos XVI-XIX (pp. 25-107). La Paz, México: Universidad Autónoma de Baja California Sur.

(2015). Ilustración y utopismo en el noroeste de Nueva España. El pensamiento económico español del siglo XviII en las proyecciones de José Rafael

${ }^{63}$ Crosby (1992, pp. 284-318).

${ }^{64}$ Trejo Barajas (1999, pp. 31-54); Ortega (2001, pp. 91-98, 123-144); Altable (2013, pp. 284-318). 
Rodríguez Gallardo y José de Gálvez. En J. E. Covarrubias (coord.), El mito de una riqueza proverbial. Ideas, utopías y proyectos económicos en torno a México en los siglos XVIII y XIX. México: Universidad Nacional Autónoma de México, Instituto de Investigaciones Históricas.

(2013). Vientos nuevos. Idea, aplicación y resultados del proyecto borbónico para la organización del gobierno y el desarrollo de la población y economía de las Californias, 1767-1825. La Paz, México: Universidad Autónoma de Baja California Sur.

(2003). La California en los caminos de la expansión española. En E. González Cruz (coord.), Historia general de Baja California Sur. Los procesos políticos (pp. 41-70). La Paz, México: Consejo Nacional para la Ciencia y la Tecnología/Plaza y Valdés Editores/Universidad Autónoma de Baja California Sur.

Bancroft, H. H. (1886). History of California, vol. 1, 1542-1900. San Francisco, California: The History Company Publishers.

Beebe, R. M., y R. M. Senkewicz (2001). Lands of Promise and Despair. Chronicles of Early California, 1535-1846. Berkeley: Santa Clara University/Heyday Books. Bernabéu Albert, S. (1992). El Pacífico ilustrado: del lago español a las grandes expediciones. Madrid: Fundación MAPFre.

CAPel, H. (1994). Miguel Constanzó y la Ilustración novohispana. Prólogo a J. O. Moncada Maya, Miguel Constanzó: un militar ilustrado en la Nueva España del siglo XVIII (pp. 11-21). México: Universidad Nacional Autónoma de México, Instituto de Geografía, Instituto de Investigaciones Sociales.

Carrera Stampa, M. (1959). La nao de China. Historia Mexicana, 1-9, julio-septiembre, 97-118.

Colección de documentos inéditos relativos al descubrimiento, conquista y organización de las antiguas posesiones españolas en América y Oceanía (1866), varios tomos. Madrid: Imprenta de Frías y Compañía.

Costansó, M. (1950). Diario histórico de los viages de mar y tierra hechos al norte de la California, año de 1770. México: Chimalistac.

Covarrubias, J. E. (2005). En busca del hombre útil. Un estudio comparativo del utilitarismo neomercantilista en México y Europa, 1748-1833. México: Universidad Nacional Autónoma de México, Instituto de Investigaciones Históricas.

Crosby, H. (1992). Los últimos californios. La Paz, México: Gobierno del Estado de Baja California Sur.

Fernández de NAVARrete, M. (1829). Colección de los viajes y descubrimientos por mar que hicieron los españoles desde fines del siglo XV (5 vols.). Madrid: Imprenta Real.

Fuster Ruiz, F. (1997). El final del descubrimiento de América. California, Canadá y Alaska, 1765-1822. Murcia: Universidad de Murcia. 
García-Abasolo GonzÁlez, A. (2002). La primera exploración del Pacífico y el asentamiento español en Filipinas. En Elizalde Pérez-Grueso, M. D. (coord.), Las relaciones entre España y Filipinas, siglos XVI-XX (pp. 21-36). Barcelona: Casa de Asia.

Landín Carrasco, A. (1992). Los hallazgos españoles en el Pacífico. Revista Española del Pacífico, 2-11, 11-29.

Lucena Salmoral, M. (2005). Piratas, corsarios, bucaneros y filibusteros. Madrid: Síntesis.

Mathes, W. M. (1965). Californiana I. Documentos para la historia de la demarcación comercial de California, 1583-1632 (vol. II). Madrid: José Porrúa Turanzas.

Moncada Maya, J. O. (2016). A la búsqueda de una utopía californiana. Miguel Constanzó y el poblamiento de la Alta California en el siglo XVIII. XIV Coloquio Internacional de Geocrítica. Las utopías y la construcción de la sociedad del futuro. Barcelona, mayo.

(1994). El ingeniero Miguel Constanzó: un militar ilustrado en la Nueva España del siglo XVIII. México: Universidad Nacional Autónoma de México, Instituto de Geografía, Instituto de Investigaciones Sociales.

Ortega Soto, M. (2001). Alta California: una frontera olvidada del noroeste de México, 1769-1846. México: Plaza y Valdés Editores/Universidad Autónoma Metropolitana.

Ortuño Sánchez-Pedreño, J. M. (2004). Las pretensiones de Hernán Cortés en el Mar del Sur. Documentos y exploraciones. Anales de Derecho, 22, 317-353.

Osante, P. (2012). Poblar el septentrión. Las ideas y las propuestas del marqués de Altamira, 1742-1753. México: Universidad Nacional Autónoma de México, Instituto de Investigaciones Históricas/Instituto Tamaulipeco para la Cultura y las Artes.

Pinzón Ríos, G. (2011). Acciones y reacciones en los puertos del Mar del Sur. Desarrollo portuario del Pacífico novohispano a partir de sus políticas defensivas, 17131789. México: Universidad Nacional Autónoma de México/Instituto de Investigaciones Dr. José María Luis Mora (Serie Historia Novohispana / 87).

(2008). Defensa del Pacífico novohispano ante la presencia de George Anson. Estudios de Historia Novohispana, 38, enero-junio, 63-86.

Portillo, A. del (1982). Descubrimientos y exploraciones en las costas de California, 1532-1650. Madrid: Ediciones RIALP.

Río, I. del (2003). El régimen jesuítico de la Antigua California. México: Universidad Nacional Autónoma de México.

(1985). A la diestra mano de las Indias. Descubrimiento y ocupación colonial de la Baja California. La Paz, México: Gobierno del Estado de Baja California Sur. Rodríguez, J. (2015). Mareantes y mareados: el estrecho de Anián y las naos de California. Romance Notes, 55, 133-144. 
Ruiz Rodríguez, I. (2013). Las fronteras septentrionales del Pacífico americano: españoles, rusos e ingleses en la conquista de la Alta California, ILCEA. Revue de l'Institut des Langues et Cultures d'Europe, Amérique, Afrique, Asie et Australie [en línea], 18. URL: journals.openedition.org/ilcea/2058, DOI: 10.4000/ ilcea.2058.

SÁnchez SAnTiRó, E. (2017). Los libros de la razón general de Real Hacienda como instrumentos de gobierno del erario de Nueva España (1786-1818): una obra inconclusa. Estudios de Historia Novohispana, 57, julio-diciembre, 79-96. doi. org/10.1016/j.ehn.2017.05.002.

Torales Pacheco, J. M. C. (2001). Ilustrados en la Nueva España. Los socios de la Real Sociedad Bascongada de los Amigos del País. México: Universidad Iberoamericana.

Trejo Barajas, D. (1999). Espacio y economía en la península de California, 17851860. La Paz, México: Universidad Autónoma de Baja California Sur.

(1991). La secularización de misiones y la colonización civil en el sur de la Baja California, 1768-1842. En J. Preciado Llamas y M. E. Altable Fernández (coord.), Sociedad y gobierno en el sur de la Baja California. Cinco aproximaciones históricas (pp. 19-63). La Paz, México: Universidad Autónoma de Baja California Sur.

Venegas, M. (1943). Noticia de la California y de su conquista temporal y espiritual hasta el tiempo presente (3 vols.). México: Layac.

Yuste López, C. (2007). Emporios transpacíficos. Comerciantes mexicanos en Manila, 1710-1815. México: Universidad Nacional Autónoma de México, Instituto de Investigaciones Históricas.

ZAMORA Y CORONADO, J. M. (1840). Registro de Legislación Ultramarina y Ordenanza general de 1803 para intendentes y empleados de Hacienda en Indias (t. 2). La Habana: Imprenta del Gobierno.

\section{SOBRE EL AUTOR}

Doctor en Historia por la Universidad Nacional Autónoma de México. Especialidad: Historia política, económica y social sobre el noroeste novohispano. Su publicación más reciente es "Esa natural tendencia del género humano. Individualismo y utopía en el noroeste de Nueva España”, Tzintzun. Revista de Estudios Históricos, n. 67, enero-junio 2018. 